\title{
Climate services to support sustainable tourism and adaptation to climate change
}

\author{
Daniel J. Scott ${ }^{1, *}$, Christopher J. Lemieux ${ }^{1}$, Leslie Malone ${ }^{2}$ \\ ${ }^{1}$ Department of Geography and Environmental Management, Faculty of Environmental Studies, University of Waterloo, \\ Waterloo, Ontario N2L 3G1, Canada \\ ${ }^{2}$ World Meteorological Organization, 1211 Geneva 2, Switzerland
}

\begin{abstract}
Tourism is one of the largest global economic sectors, is a vital contributor to the economy of many nations, and is highly promoted as an important means of future development and poverty reduction in developing countries. The interface between climate and tourism is multifaceted and complex, with broad significance for tourist decision-making and expenditures, as well as industry marketing and operations worldwide. With the close relationship of tourism to the environment and climate, the integrated effects of climate change are anticipated to markedly affect tourism businesses and destinations, as well as the destination choices and mobility of individual tourists in the decades ahead. As recent major natural, political, and economic shocks have demonstrated, the tourism sector has relatively high adaptive capacity. Improved climate services will be vital for travelers and tourism businesses and destinations to adapt to climate change in an economically, socially, and environmentally sustainable manner. This paper outlines the range of applications of weather and climate information within the tourism sector and discusses priorities for future work to advance climate services for weather risk management and climate change adaptation for the tourism sector.
\end{abstract}

KEY WORDS: Climate change $\cdot$ Climate variability $\cdot$ Weather $\cdot$ Tourism $\cdot$ Sustainability $\cdot$ Adaptation Climate services $\cdot$ Development

\section{INTRODUCTION}

The tourism sector is one of the largest and fastestgrowing global industries and is a significant contributor to national and local economies around the world. The economic importance of the sector worldwide is demonstrated by the World Travel and Tourism Council's (2010) estimates that in 2008 the global travel and tourism industry contributed $9.6 \%$ of global gross domestic product (GDP) and 7.9\% of worldwide employment. According to the United Nations World Tourism Organization (UNWTO 2009), international tourist arrivals have grown from just over 200 million in 1980 to 922 million in 2008, and are expected to grow to 1.6 billion (billion $10^{9}$ ) arrivals by 2020 (UNWTO 2001). While comparable global information on domestic tourism is not available, the UNWTO (L. Cabrini, Director of Sustainable Development of Tourism, UNWTO, pers. comm. 2009) estimates that 8 billion trips were made worldwide in 2005 (4 billion same-day visitors and 4 billion overnight visitors).

While the majority of international tourism currently occurs in developed countries, the sector is a vital contributor to the economy of many developing countries. Between 1995 and 2007, it is estimated that international tourism in emerging and developing markets grew at twice the rate of industrialized countries - by $11 \%$ for least-developed countries (LDCs) and 9\% for other low- and lower-middle-income economies (UNWTO 2008). Visitor spending represented >10\% of national GDP in 36 developing countries in 2006 (UNCTAD 2008). The UNWTO (2007) also estimates that tourism is a primary source of foreign-exchange earnings in 46 out of 50 of the world's LDCs. With the growth of tourism in developing countries, international tourism is frequently promoted by development 
organizations and many governments as having an important role in contributing to the United Nations (UN) Millennium Development Goals, particularly the alleviation of poverty in LDCs, gender equality, and environmental sustainability.

The tourism sector is characterized by considerable diversity. Tourism subsectors include transportation, accommodation, food and hospitality services, travel agents, visitor attractions, retail and other services (such as insurance). Tourism operators differ in terms of ownership (government, nongovernmental organizations, private businesses), size (there is a predominance of small and medium-sized enterprises in the sector, but also many international conglomerates), and purpose (for profit or non-profit, as well as heritage-natural conservation, education, and community development mandates). Tourism operators have adapted to provide tourism services in every climatic zone on the planet and are affected by climate in a number of ways. All tourism destinations are climatesensitive to a degree in that they are influenced by natural seasonality and demand, which are defining characteristics of tourism worldwide. Tourism destinations are affected either positively or negatively by interannual climate variability that brings heat waves, unseasonable cold, drought, storms, and heavy rain, which can affect not only tourist comfort and safety (and thereby satisfaction), but also the products that attract tourists (e.g. snow cover, coral reefs) or deter them (e.g. infectious disease, wildfires, tropical cyclones, heat waves). Climate variability also influences various facets of tourism operations (e.g. water supply and quality, heating-cooling costs, snowmaking requirements). An international survey of 66 national tourism and meteorological organizations found that a large majority $(81 \%)$ felt that weather and climate were major determinants of tourism in their nation (Wall \& Badke 1994). As a consequence of this diversity, there are extensive differences in the nature of climate sensitivities and abilities of tourism operators worldwide to incorporate climate services into decision-making.

Equally as diverse are the motivations and characteristics of domestic and international travelers. Weather and climate have a broad significance to tourist decision-making and the travel experience, significantly influencing travel patterns and expenditures worldwide. Climate is a key factor considered by tourists, consciously or implicitly during travel planning, and represents both a push and pull factor for tourists. Weather and climate are an intrinsic component of the vacation experience and have been found to be a central motivator for travel (Mintel International Group 1991, Lohmann \& Kaim 1999, Kozak 2002, Hamilton \& Lau 2005, Gössling et al. 2006, Hill 2009, Moreno 2010). Climate variability has been found to influence travel patterns (proportion of domestic and international holidays) and tourism expenditures in some nations (Smith 1990, Jorgensen \& Solvoll 1996, Giles \& Perry 1998, Wilton \& Wirjanto 1998, Bigano et al. 2005, Agnew \& Palutikof 2006, Jones \& Scott 2006, Moreno et al. 2008). There is also evidence that the weather conditions experienced at the destination have important influence on travel and holiday satisfaction (Smith 1993, Carmichael 1996, König \& Abegg 1997, Williams et al. 1997, Bicknell \& McManus 2006, Scott 2006). The disparate climate requirements for the major tourism market segments (e.g. sun and beach, sports, adventure, urban), as well as between groups within each major market segment (e.g. golf, ski, and windsurfing segments of sports tourism), create very different demand-side climate sensitivities and information requirements among tourists.

As this evidence (preceding paragraph) indicates, the relationship between climate and tourism is multifaceted as shown in Fig. 1 which outlines the temporal scales (extreme events, seasonality, inter-annual variability, climate change) at which climate influences different subsectors of the tourism system, either directly (blue lines) or indirectly (black and red lines). Overall, accumulating evidence indicates that the integrated effects of climate change (both shifts in climatic means and extremes) could have profound impacts on tourism businesses and destinations. Because climate, the natural environment, personal safety, and travel cost are primary factors in travel decisions, far-reaching shifts in consumer travel demand may also occur (Gössling \& Hall 2006, Scott 2006, Becken \& Hay 2007 , Scott et al. 2008a).

Although applied climatologists and the tourism community are only beginning to unpack the complexity of these varied interactions and the implications of climate change, what is clear is that the demands for accurate and increasingly detailed climate information will increase as tourism businesses and destinations wish to minimize associated risks and capitalize upon new opportunities posed by climate change in the decades ahead.

Despite the growing global economic importance of the tourism sector and the multiple, complex interactions between climate and tourism, there have been very limited evaluations of the use of climate information or assessments of the climate-services needs within the tourism sector (Altalo \& Hale 2002, de Freitas 2003, Scott 2006, McBoyle 2007). Section 2 provides an overview of the current and emerging applications of climate services in the tourism sector, including the varied roles of weather and climate information providers and various delivery pathways of climate information to tourism end-users, and the key entry points for decision-making by tourists and major 


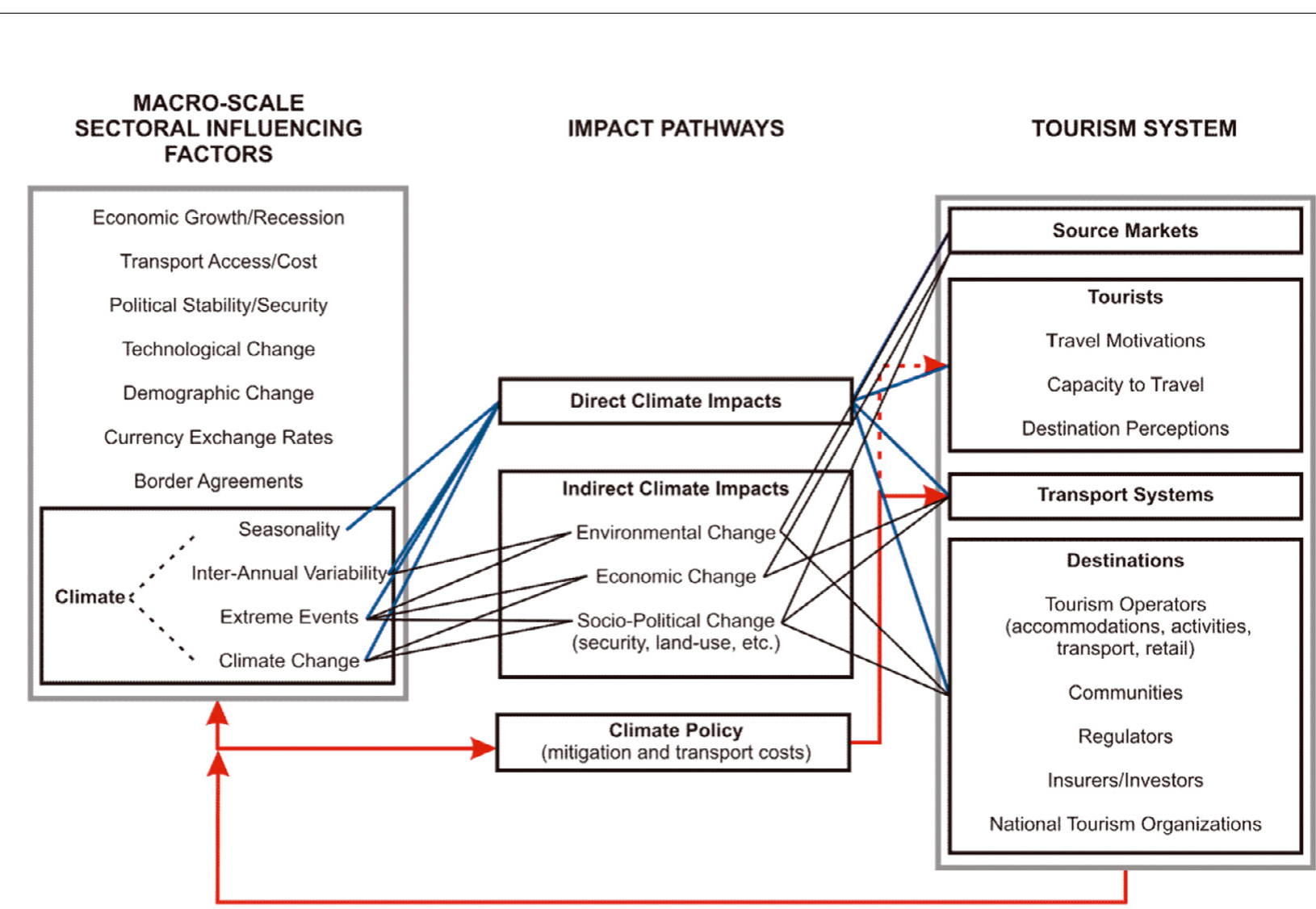

Fig. 1. Climate influences on the tourism sector. Influences are direct (blue line) or indirect (black line, red line). Black lines: indirect effects from climate-induced environmental change. Red lines: indirect effects of climate change policy and mitigation on tourism along with tourism's contribution to GHG emissions

categories of tourism operators. Section 3 discusses key knowledge gaps and the partnerships and capacity building that are required to advance the application of climate information in the tourism sector in the near-term and support successful adaptation to climate change in the longer term.

\section{CLIMATE INFORMATION IN SUPPORT OF TOURISM}

\subsection{Supply}

There has been a proliferation of weather and climate information providers and communication technologies over the past 2 decades, and the types of information available to tourism end-users from major providers varies considerably from nation to nation and even within nations. Fig. 2 provides a conceptual framework of the supply of climate information and services to endusers in the tourism sector. National meteorological services (NMS) and private meteorological companies (e.g. The Weather Network ${ }^{\circledR}$, Canada; The Weather Channel ${ }^{\circledR}, \mathrm{USA}$; BBC Weather, UK) are the primary sources of weather and climate data, which is then delivered to tourism end-users by a wide range of providers with different objectives.

The quantity and diversity of specialized weather and climate services provided by NMS to the tourism sector is currently limited (provision of aviation and marine forecasts central to tourism transport being the key exception); however, some of the joint government and WMO demonstration projects of nowcasting ${ }^{1}$ systems and applications have focused on major sporting and tourism events (the Summer Olympic Games in Sydney, Australia, and Beijing, China). NMS have a critical role in supplying much of the climate information to the mass media and other tourism-specific outlets (e.g. tourist guides, marketing brochures, travelplanning websites) and provide the essential historical, current, and forecast information that allows other

\footnotetext{
1 Nowcasting is a form of very short-range weather forecasting, covering only a very specific geographic area. A nowcast is loosely defined as a forecast for the coming $12 \mathrm{~h}$ period, based on very detailed observational data. A more restrictive definition of a nowcast is a detailed description of current weather conditions, from which one can extrapolate (project) the weather conditions for the following $2 \mathrm{~h}$. Source: McGraw-Hill Encyclopedia of Science and Technology, 7th edn., vol. 12, p. 116.
} 
providers to develop specialized climate products for the tourism sector. As with all climate-sensitive economic sectors, the maintenance and enhancement of the global climate-monitoring network is in the best interest of the tourism sector. Certain key tourism environments are notably underserviced by the global meteorological observation system, particularly coastal, mountain, and small-island destinations.

\subsection{Accuracy and interpretation}

Climate information represents a double-edged sword for the tourism sector, for while accurate climate information can be invaluable to the tourism industry, inaccurate climate information or weather warnings that deter visitation are often more detrimental than the adverse weather itself. Recent seasonal forecasts have also adversely affected travel decisions in the UK. In 2009, travel agents and tour operators observed that following the NMS's long-range summer forecast of 'unusually warm, dry weather with heat waves up to $30^{\circ} \mathrm{C}^{\prime}$, demand for foreign holidays declined substantially (Hill 2009). After a very rainy month of July and a revised forecast for 'wet weather until September', the Association of British Travel Agents reported an increase in travel bookings of up to $40 \%$ and a diminished supply of package holidays to sunshine destinations (Hill 2009). The improved accuracy of weather forecasts has also been identified as an important concern of, and as a requirement for, increased use in operational decision-making in the tourism sector by the stakeholders at workshops we attended in the USA, Spain, Jamaica, Bahamas, Fiji and Greece, and also by Altalo \& Hale (2002) and Gamble \&
Leonard (2005). The accuracy of weather forecasts was an important topic of discussion at the Secure and Sustainable Living: Social and Economic Benefits of Weather, Climate and Water Services conference in Madrid (WMO 2007):

Accurate, geographically specific meteorological information is essential for tourism operations. General forecasts, though meteorologically accurate, often have a negative impact on tourism operations because tourist destinations, such as beaches, coastal areas and mountains are often regions with unique and better than average microclimates. ... (climatic conditions) which would attract tourists, may differ substantially from prevailing regional conditions. (L. Cabrini, Director of Sustainable Development of Tourism, UNWTO)

\subsection{Private-sector service providers}

Private sector weather and climate service providers have, to a great extent, embraced the rapid technological advancements that have occurred over the past decade with respect to meteorological observations and communication systems (i.e. advances in cable television, the internet, and more recently smartphones) to provide user-friendly access to climate information. Private-sector climate service providers have led the way in terms of innovation of specialized climate services tailored to specific tourism destinations, individual tourist activities, and subsectors. Private meteorological companies in the USA (e.g. The Weather Channel ${ }^{\circledR}$, Accuweather ${ }^{\circledR}$ ) and in Europe (WeatherNet) offer specialized weather reports and climate 'indices' for several recreation and tourism sub-sectors (e.g. golf, skiing, special events and major

\section{CLIMATE INFORMATION SOURCE CLIMATE INFORMATION
\& SERVICE PROVIDERS \\ TOURISM SECTOR END-USERS}

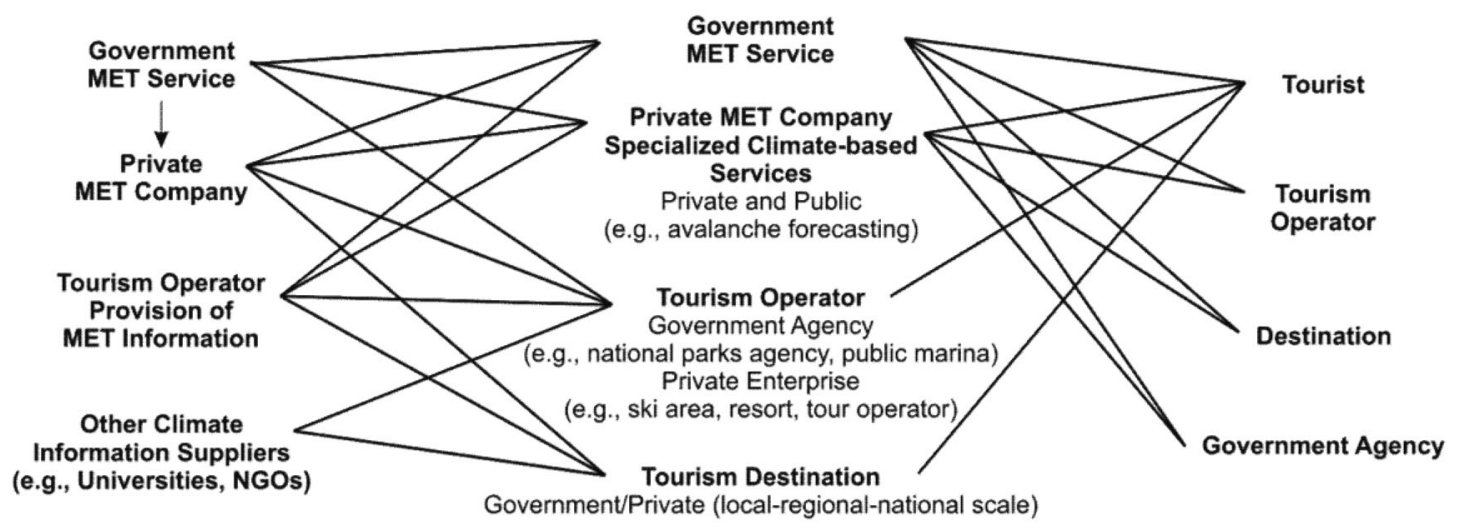

Fig. 2. Conceptual framework of climate information in the tourism industry. MET: meteorological, NGO: nongovernmental organization 
sporting events, weather-sensitive travel routes, coastal beach and international sunshine destinations) as well as a range of forecast products tailored to recreation and tourism sector operations (e.g. snowmaking, golf turf management, marine forecasts, and weather risk insurance assessments). The emergence of new specialized tourism weather and climate products from private meteorological companies represents important progress, but thus far lacks the transparency needed to properly evaluate their rigor and applicability to the international travel marketplace.

Private sector climate service providers have been innovators in the use of emerging communications technologies to deliver specialized climate information to tourists and other tourism-sector end-users. Both the Apple $^{\circledR}$ App Store $^{\mathrm{TM}}$ and the BlackBerry ${ }^{\circledR}$ App World ${ }^{\mathrm{TM}}$ provide a number of specialized weather applications tailored to specific tourism-related activities: skiing (iSki App, The North Face ${ }^{\circledR}$ Snow Report, SkiResort, and SnoCountry), boating (TideApp), surfing (Oakely ${ }^{\circledR}$ Surf Report), and fishing (Fishing Calendar). With the number of mobile phones expected to exceed 4 billion in 2010, these specialized applications are likely to further revolutionize how outdoor recreationists and travelers receive and utilize weather and climate information over the next decade. to $1 \mathrm{~h}$ ), to short- and medium-range forecasts ( 1 and $7-10 \mathrm{~d})$, to multi-decadal climate-change projections, is being utilized in a wide range of decision-making contexts by tourism operators and planners (Fig. 3). Historical climate information can be used for strategic planning of tourism infrastructure, including: location analysis for new resorts, architectural and landscape design, to construction scheduling in remote locations. The limited availability of historical climate information in many developing nations and remote locations (e.g. smaller islands and mountainous areas) at the scale relevant to tourism developers has posed a barrier to its use in the past. Altalo \& Hale (2002) found that weather and climate were not usually cited as reasons for development of new resorts relative to other macro-level factors like transportation access, source markets, land ownership, and coastal access, but were utilized more extensively in engineering, construction planning, property design and maintenance, and other post-build decisions (e.g. insurance, heating-cooling, budgeting and staffing).

Historical climate data is also the foundation for the emerging application of innovative weather derivatives and index insurance products to reduce weather risk in the tourism sector. Participation of the tourism

\subsection{Use and applications}

The potential use of climate information within the tourism sector is tremendous given the high number and diversity of end-users. The full temporal scale of weather and climate information, from nowcasting (up

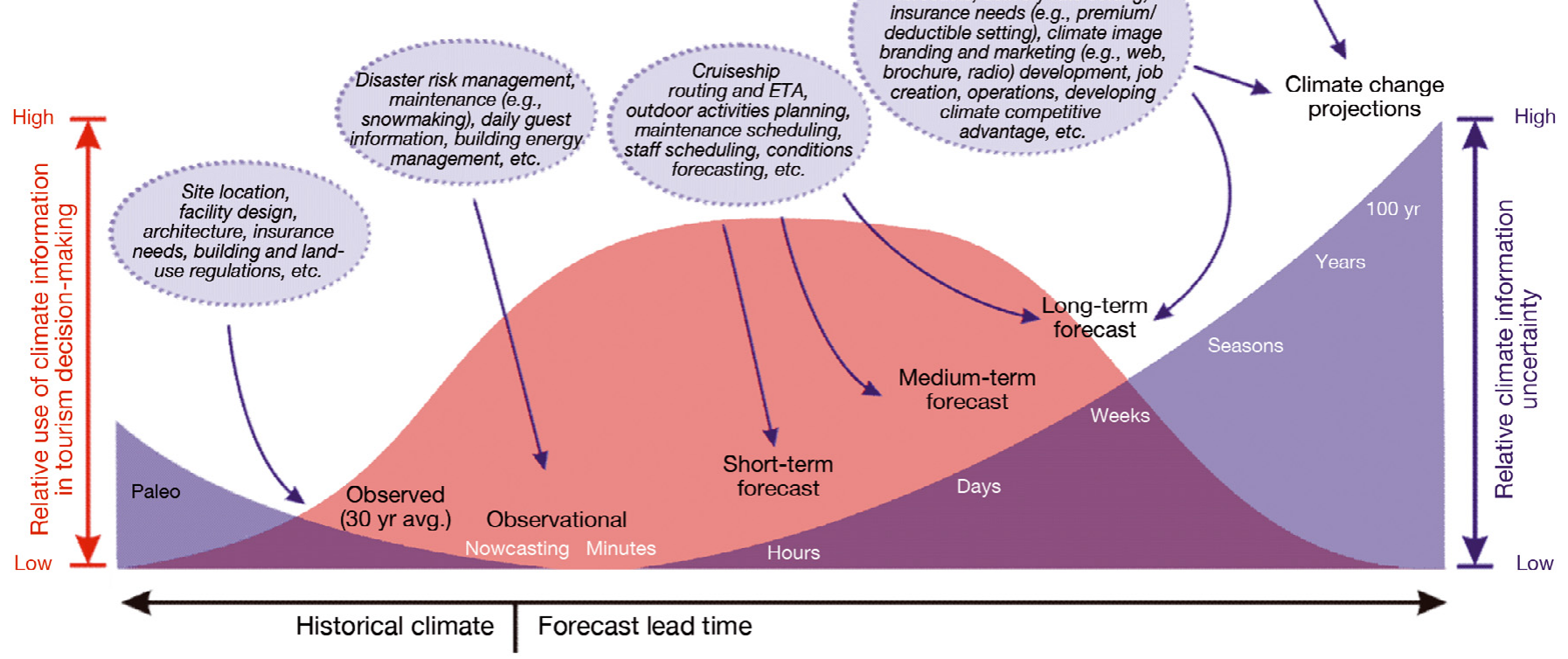

Fig. 3. Potential uses of weather and climate information by tourism operators and travel planners. ETA: estimated time of arrival 
sector in the weather derivatives market has remained rather limited. Knowledge of just how dependent different tourism sub-sectors and specific businesses are on weather is still relatively unexplored and is hampering development of weather risk-sharing financial products within the tourism sector. Nonetheless, there is tremendous potential to develop innovative partnerships with the financial services sector to develop highly customized contracts aimed at preventing or reducing weather-related revenue loss and creating new destination-marketing strategies that deliver a competitive advantage regardless of actual weather conditions.

Tourism operators and organizations that promote tourism to specific destinations typically utilize historical climate information for 2 purposes: (1) marketing the destination and (2) assisting travelers to prepare for a safe and comfortable travel experience. Reviews of the advertising of destinations have consistently found that climate is used positively in virtually all forms of marketing and destination image creation (Lanquar \& Hollier 1986, Gómez Martín 1999, Gómez Martín \& Palomeque 2001), often with a very obvious 'blue sky' bias (Besancenot 1991, Perry 1993). According to Besancenot (1991, p. 208), 'the iconographic analysis of tourist brochures and the careful reading of the accompanying text only confirm the obsessive presence of references, direct or indirect, to the climate'. Some destinations have cultivated a destination image and marketing strategy around certain activities or experiences that are largely based on the local climate. The Cayman Islands promotes its 'perpetual summer', while the US state of Florida brands itself as 'the sunshine state'. In an effort to differentiate the climate-based destination image of Barbados, its tourism authority began offering a 'perfect weather guarantee' in 2009 (Holland 2009). Similar 'money-back sunshine guarantees' have begun to be offered for destinations in the south of France by travel agents in France in cooperation with the insurance company Aon France (Allen 2009).

In destinations where seasonal weather is not highly conducive to tourism, climate is sometimes downplayed in marketing communications or is specifically addressed to overcome unfavorable perceptions. For example, a tourism brochure for Brittany, France, informs tourists that 'common misconceptions and prejudices have portrayed Brittany as a rainy region when in fact its maritime climate is mild and bracing ... (and its) iodine-rich sea air is unique and just to breathe it in is to enjoy its health-giving properties' (Brittany Tourism 2006, p. 7). Other destinations use what would typically be considered adverse weather conditions to develop distinct tourism products. Historically, tourism has not been an important activity to the local economy of Tarifa, Spain, as the frequent high winds were not suitable for conventional sun-and-sea tourism development. However, the high winds of Tarifa are a very valuable resource for water sports such as windsurfing and kitesurfing, and the community now markets itself as the 'windsurfing capital of Europe' or the 'Costa de la Luz y el Viento' (the Coast of Light and Wind). Vancouver Island (British Columbia, Canada) promotes a storm watching product (Vancouver Island Tourism 2010) on its Pacific Ocean coast during the fall and winter months and encourages visitors to take advantage of the special conditions created during the La Niña phase of the El Niño-Southern Oscillation.

In the same way that historical climate information has been used for strategic planning of future tourism developments, climate-change projections are now also being utilized to anticipate and adapt to market risks and opportunities at the business, destination, and national level. While the use of climate-change information by tourism developers, operators, and destinations remains isolated to date, its necessity for successful climate-change adaptation is anticipated to increase substantially in the decades ahead.

Tourism operators use climate information, particularly real-time observations and short-term forecasts, extensively. Recent weather observations are important inputs into a range of decision-support tools, including: automated turf management systems used by golf courses and other sports facilities, snow production systems used by ski areas, cruise ship and aviation routing, fire and avalanche warning systems, and energy system management (heating-cooling). However, as Altalo \& Hale (2002) point out, despite the acceptance of seasonal and weather influences on tourist flows by the accommodation and hospitality sub sectors, there are no widely applied business forecast or revenue models allowing for climate or weather data input.

Real-time observations and near-term weather forecasts are also used extensively by tourism operators for marketing purposes. Tourism operators provide current observations (including webcams) and short-term forecasts to promote their location or event to tourists. Other innovative marketing strategies that utilize forecast information to tailor marketing messages or target certain markets have emerged recently. The emergence of 'flash selling' in the lodging industry, where hotel operators utilize massive email distribution lists generated by customer and loyalty program databases or prearranged internet marketing arrangements, targeting last minute and short lead time bookings ( 1 to $5 \mathrm{~d}$ ) with specially designed packages and deals, is increasingly using forecasts to tailor tourism packages to anticipated weather (e.g. a weekend golf or theater package depending on weather conditions). In other cases, tourism operators monitor forecasts in nearby regional markets, 


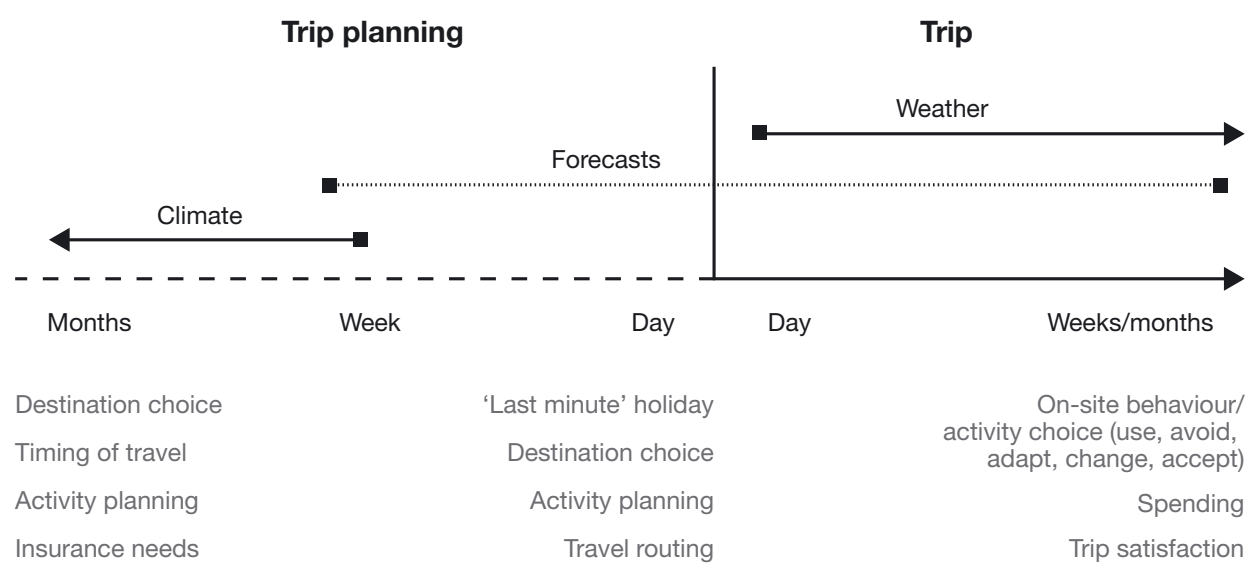

Fig. 4. Weather and climate information for leisure tourist decision-making

and when poor conditions are forecast in those regions, the tourism operators target market those locations with 2 day specials for weekend activities and pleasant weather (B. Farren, Pinehurst Resort and Country Club, Greenville, NC, pers. comm. 2008).

\subsection{Tourist decision-making}

Weather and climate have broad significance to tourist decision-making and the vacation experience. Fig. 4 conceptualizes the influence of different types of climate information (historical, forecasts, nowcasts) on tourist decision-making, from the trip planning to the travel phase and the destination itself. The limited studies that have examined the use of climate information by travelers reveal widespread use in holiday planning (Adams 1973, Smith 1981, Hamilton \& Lau 2005, Rutty \& Scott 2010). Interestingly, consideration of current weather conditions or near-term forecasts (the next 1 to $4 \mathrm{~d}$ ) has been found to be the most important factor in 'last-minute' domestic leisure tourism (Szalai \& Ratz 2006). With the trend toward shorter timeframes for travel planning, especially discounted 'last-minute' bookings made in the week (or day) prior to departure, the relevance and value of accurate short- and medium-term forecasts for travel planning is increasing. Business travelers are particularly cognizant of how weather causes delays and diversions and utilize forecasts in routing decisions.

\section{INFORMATION SERVICES FOR CLIMATE- CHANGE ADAPTATION}

All major tourism businesses and destinations, regardless of whether they are potential 'winners' or 'losers' from climate change, will need to adapt in order to minimize associated risks and capitalize upon new opportunities, in an economically, socially, and environmentally sustainable manner. Climate-change adaptation is knowledge-intensive, and access to climate services will be an important prerequisite for successful adaptation in the tourism sector. In order to meet the needs of the tourism industry and destination communities for adaptation to climate variability and change, the following 4 gaps in climate services for tourism need to be addressed.

\subsection{Quality and applicability}

Effective decision-making requires the right climate information not only in terms of the quality of the data, but in terms of its applicability to tourism operators and specific activities pursued while traveling.

In many tourism locations, particularly in developing countries, historical climate information has been unavailable for tourism planning because meteorological networks are not present (or lack electronic archiving) or do not adequately represent the climatic conditions in specific tourism destinations. Climate information in regions with spatially coarse meteorological networks have reduced applicability to decision-making in the tourism sector, because activity patterns and tourism operations are highly localized, often in microclimate conditions (e.g. mountain valleys, high elevations, coasts, or small islands). In this review of the types of climate information provided by destinations or tourism operators, it was observed that in a number of cases, the climate station used by operators or destination promoters was located $>100 \mathrm{~km}$ away from the destination (sometimes far greater). Weather information being communicated to potential users may therefore differ substantially from the prevailing local conditions.

Issues of availability and representativeness of climate data for tourism destinations are likely to encumber climate-change adaptation and the further devel- 
opment of weather-risk sharing financial products within the tourism sector. It is almost impossible to develop an effective climate-change adaptation strategy without knowledge of past climate and how this baseline is projected to change in the future. The pricing of weather derivative contracts and the right of a customer to receive payment for adverse or unexpected weather conditions are based on weather statistics and observations at individual weather stations with a high-quality historical record, and are not contingent upon conditions at a specific business location (e.g. ski area, golf course) or event (e.g. music concert). The coarser the meteorological network, the less representative the conditions at the nearest weather station may be, depending on distance and local geography. The lack of sufficient weather stations and availability of adequate data reduces the potential application for weather-risk reduction through weather risk-sharing products like derivatives and weather index insurance. These issues are particularly acute in rural areas and some developing nations where tourism is a major part of the economy-areas that could benefit significantly from weather risk management products.

Investment is required to strengthen climate-monitoring networks in areas where the tourism sector is vital to local economies, specifically rural areas and many developing countries (particularly small island states), in order to improve climate risk management and climate-change adaptation in the tourism sector. With the risk of permanent loss of historical climate data in developing countries, which have potentially high value for managing climate risk and informing climate-change adaptation, data rescue should be a core component of initiatives to improve climate data for tourism. Strengthening of climate-monitoring networks is required to support the development and access to innovative financial products (weather derivatives and index insurance) to manage climate risk in the tourism sector. Innovative government and private sector partnerships to expand the climate monitoring network for tourism should be explored.

\subsection{Decision-making}

Knowledge about the process of how tourism endusers integrate weather and climate information into specific decisions remains very limited.

Key knowledge gaps remain regarding the decisiveness of weather and climate as a factor in decisionmaking and when end-users require climate information in different decision-making processes. The proportion of tourists traveling primarily for climaterelated motivations or to engage in climate-sensitive activities remains unknown yet it is central to understanding the relative climate sensitivity of destinations. Conceptualizing the decision-making process requires, at a minimum, describing the key decision-makers, their goals, the context in which they operate (i.e. the decision-making environment), the information they use to make decisions, the alternative actions available to them, and the important decision points. Climate information is typically embedded with other relevant information (Adams 1973, de Freitas 2003, Stewart et al. 2004, Scott 2006), and disentangling the role of climate and its relationship to other situational factors in major decision-making processes in tourism remains an important objective for future research.

Tourists experience and respond to the integrated effects of the weather elements that comprise climate (Mieczkowski 1985, de Freitas 2003, de Freitas et al. 2008, Scott et al. 2008b). However, there remains an incomplete understanding of the relative importance of different climate parameters to tourists, the range of climate preferences among tourists in terms of the optimal conditions and thresholds of unacceptability for certain variables, how preferences differ for specific tourism environments or destinations, and whether significant cultural, regional, or market segment differences exist in climate preferences (Gómez-Martín 2006, Scott et al. 2008b, Moreno 2010, Rutty \& Scott 2010). The complexities of tourist climate preferences are only beginning to be examined. Multi-disciplinary and cross-cultural research is required to understand whether similar climate preferences exist among tourists from other climatic regions of the world as well as to understand the particular climate sensitivity of specific tourism activities.

Fundamental knowledge of climate conditions that strongly influence destination choice and activity satisfaction is a prerequisite to the development of specialized climate products for the tourism sector. Without it, the validity of specialized indices being communicated by private weather media and those in the research literature (e.g. 'Tourism Climate Index', Mieczkowski 1985) remain uncertain. Unfortunately, most of the newly developed specialized products from private meteorological companies lack transparency in the methods and data sources to properly evaluate their application to either domestic or international travelers. These specialized products will serve to inform destination and activity choices, and in some cases affect decisions that have implications for the personal safety of travelers. Consequently, their design must be transparent to the research community and tourism professionals to facilitate validation in the tourism marketplace. Furthermore, the tourism sector, in collaboration with NMS, private meteorological companies, and university researchers, is encouraged to develop 
accepted international standards for specialized climate products, to ensure consistent and accurate communication of climate information to international travelers, and to facilitate objective destination comparisons and marketing claims in a global tourism marketplace.

\subsection{Societal benefits}

Effective use of climate information has the potential for avoiding injury and death, averting property and environmental damage, and a wide range of other societal benefits (Stewart et al. 2004).

There is a growing literature on the economic value of climate information and forecasts (Katz \& Murphy 1997) as well as techniques to evaluate non-market benefits. Although Altalo \& Hale (2002) contend that the financial benefits of weather and climate information for the tourism sector are likely to be very substantial, the tourism sector is virtually absent from this literature. Moreover, there are no known studies of the financial or non-market benefits of specialized products for tourism or the 'willingness to pay' for climate information among tourists and tourism operators. Consequently, the value of climate information to tourists and the tourism industry remains unknown. Tourists are very willing to pay for a quality tourism experience, and thus, hypothetically, if tourists were willing to pay only 1 Euro for weather and climate information needed for trip planning for each of the estimated 900 million international and 8 billion domestic trips, then the global value of climate services for tourism would be very significant even without any consideration of its value for supply-side operations and marketing. Based on the success of studies that have applied techniques for economic and social valuation of climate services (market prices, normative market models, and contingent valuation studies) in other economic sectors, it is clear that uncovering the potential value for the tourism sector, and how to fully realize that potential, remains a critical area for future inquiry.

\subsection{Communication}

The production of climate information alone is not sufficient for travel or business planning and decisionmaking.

Information must be delivered to end-users in a form that is relevant to them and that they have the capability to interpret. As outlined in Fig. 2, there are a range of communication channels for the delivery of climate information to tourists and the tourism sector. Successful attempts to provide understandable, familiar, and consistent international meteorological information that could be used by tourists do exist (e.g. the adoption of the World Health Organization UV index, the international standard for UV measurement), but how climate information is communicated to tourists and tourism sub sectors remains largely unexplored. Moreover, communication channels, especially related to warnings of abrupt and dangerous weather events, are not widely documented within the tourism sector. There has been almost no evaluation of what sources of climate information tourist or tourism operators utilize, nor of the effectiveness of different communication pathways and formats. Regional consultations with major tourism end-users about their needs for climate information is required in order to adequately represent specific information needs and the capabilities of regional providers.

Gamble \& Leonard's (2005) study is the only known attempt to identify web-based tourist preferences for climate information. Examining the communication of coastal climatology information, the authors found that 'simple websites' were perceived by tourists to be most effective and included: (1) a limited amount of information presented on the website, (2) efficient and clear web navigation features, (3) limited use of scientific jargon and graphics, and (4) limited use of colors and 'flashy' graphics. These findings stand in strong contrast to recent highly technical communication tools developed by the biometeorological science community for conveying climatological information to tourists and the tourism industry (see Zaninovic \& Matzarakis 2009). There is a clear need to test these findings and the available communication tools for universal applicability across the breadth of tourism-related climate information products available to end-users.

Uncertainty is a fundamental characteristic of weather and seasonal climate forecasts. Effective communication of uncertainty helps people better understand the likelihood of a particular weather event and improves their ability to make decisions based on the forecast. Without this information, however, forecasts can easily be misinterpreted and potentially misused in decision-making (National Research Council 2006). Social science research conducted during the last decade has highlighted the difficulty in preparing visitors to effectively respond to warning messages (Drabek 2000, Sorensen 2000). Tourists can be particularly vulnerable to natural hazards because they often visit highly dynamic environments and may have limited familiarity with the places they are visiting and with common meteorological hazards, and remote locations can lack communication channels for public warnings of impending hazards. Furthermore, because tourists can be unfamiliar with the local language and are less likely to utilize local media information sources 
(either purposely or unintentionally), tourists are less likely to receive hazard warnings when they are issued, and prompt communication with them about imminent climatic hazards poses a particular challenge (UNWTO 1998). Accordingly, tourism should be taken into account in the development and implementation of any disaster-prevention program. Disaster-management units, program developers, and the tourism sector in general should proactively and collectively work towards developing and evaluating best practices for communication of climate information, particularly specialized products, forecast uncertainty, and hazard warnings to tourism end-users.

\section{CONCLUSIONS}

Although interest in the climate-tourism interface has increased markedly during the past decade, as evidenced by a doubling in the number of scientific publications on tourism and climate (with most focused on the implications of climate change) between 19951999 and 2000-2004 (Scott et al. 2005), the research community has yet to evaluate how the revolution in climate information and information communication technologies has translated into improved decisionmaking in the tourism sector. There has been no systematic evaluation of the extent and nature of climateinformation use in any tourism or specific destination region. As a result, there is limited understanding of the role of climate information in specific decision processes within the tourism sector (either demand or supply-side), the economic and non-market value of climate services to end-users and society, or the most effective ways to communicate climate information to diverse tourism end-users. These fundamental knowledge gaps must be addressed in order to facilitate the mainstreaming of climate considerations to reduce contemporary climate risk and support climate-change adaptation in the tourism sector. This can only be accomplished through interdisciplinary collaboration between governments, universities, communities, and the private sector (tourism businesses, meteorological service companies, and financial services).

Over a decade ago, Smith (1993, p. 389) argued that the limited understanding of the complex interactions of climate and tourism was in large measure because 'meteorologists and leisure specialists rarely communicate with each other'. With the increasing recognition of the need for society to adapt to future climatic change regardless of the success of international mitigation efforts (Anderson \& Bows 2008, Parry et al. 2009) and evidence that tourism is one of the more vulnerable global economic sectors (UNWTO-UNEP-WMO 2008, KPMG 2008), the time has come for the conver- sation between climate service providers and the tourism community to begin in earnest. National and regional workshops and conferences will be needed to address context-specific issues and help bridge the gap between information providers, service providers, and end-users. Positively, tourism sessions at several high-level conferences, including Living with Climate Variability and Change (Espoo, Finland, 2006), Secure and Sustainable Living: Social and Economic Benefits of Weather, Climate and Water Services (Madrid, 2007), World Climate Conference-3 (Geneva, 2009), Climate Change and Tourism: Responding to Global Challenges (Davos, Switzerland, 2007) and the joint WMO and UNWTO Expert Team on Climate and Tourism (established in 2005), have begun to forge new partnerships required to strengthen the connectivity between climate services and the tourism sector.

Acknowledegements. Portions of this paper are drawn from a discussion paper we presented at the World Climate Conference-3 in Geneva (30 August 2009). The consultations and review comments provided by the following experts on the discussion paper are gratefully acknowledged: B. Abegg (University of Zurich), S. Becken (Lincoln University, New Zealand), L. Cabrini (United Nations World Tourism Organization, Spain), J. P. Ceron (Meteo, France), C. de Freitas (University of Auckland), S. Gössling (Western Norway Research Institute), M. Hall (University of Canterbury, New Zealand), B. Jones (Parks Canada), G. McBoyle (University of Waterloo), and N. Trotz (Caribbean Climate Change Centre, Belize). Financial support from the Canada Research Chairs program, Social Sciences and Humanities Research Council of Canada (SSHRC) and Fulbright Canada is greatly acknowledged.

\section{LITERATURE CITED}

Adams R (1973) Uncertainty in nature, cognitive dissonance, and the perceptual distortion of environmental information: weather forecasts and New England beach trip decisions. Econ Geogr 49:287-297

> Agnew M, Palutikof J (2006) Impacts of short-term climate variability in the U.K. on demand for domestic and international tourism. Clim Res 31:109-120

Allen P (2009) Sunshine or your money back: French holiday companies take a gamble on the weather. Daily Mail, London, 20 July. www.dailymail.co.uk/travel/article-1200739/ Sunshine-money-French-holiday-companies-gamble-weather. $\mathrm{html}$ ?ITO=1490

Altalo M, Hale M (2002) Requirements of the U.S. recreation and tourism industry for climate, weather and ocean information. Consultants report. NOAA, Boulder, CO

Anderson K, Bows A (2008) Reframing the climate change challenge in light of post-2000 emission trends. Philos Trans R Soc Lond A 366:3863-3882

Becken S, Hay J (2007) Tourism and climate change: risks and opportunities. Channel View Publications, Clevedon, UK

Besancenot J (1991) Clima y turismo. Masson, Barcelona

> Bicknell S, McManus P (2006) The canary in the coalmine: Australian ski resorts and their response to climate change. Geogr Res 44:386-400 
Bigano A, Goria A, Hamilton J, Tol R (2005) The effect of climate change on extreme weather events and tourism. Working paper 2005.30, Fondazione Eni Enrico Mattei, Milan. http://www.feem.it/userfiles/attach/Publication/ NDL2005/NDL2005-030.pdf

Brittany Tourism (2006). Practical guide to Brittany. CRT Bretagne. http://rmhf2009.com/troach510/Travel-Books/ France/(travel-France) \%20Practical\%20Guide\% 20to\% 20Brittany\%20(2006).pdf

Carmichael B (1996) Conjoint analysis of downhill skiers used to improve data collection for market segmentation. J Travel Tourism Mark 5:187-206

de Freitas CR (2003) Tourism climatology: evaluating environmental information for decision making and business planning in the recreation and tourism sector. Int J Biometeorol 48:45-54

de Freitas CR, Scott DJ, McBoyle G (2008) A second generation climate index for tourism (CIT): specification and verification. Int J Biometeorol 52:399-407

Drabek TE (2000) Disaster evacuations: tourist-business managers rarely act as customers expect. Cornell Hotel Restaur Adm Q 41:48-57

Gamble DW, Leonard LW (2005) Coastal climatology products for recreation and tourism end users in southeastern North Carolina. NOAA Coastal Services Center, Charleston, SC

Giles A, Perry A (1998) The use of a temporal analogue to investigate the possible impact of projected global warming on the U.K. tourist industry. Tourism Manage 19:75-80

Gómez Martín MA (1999) El clima como activo del turismo: los folletos turísticos catalanes. In: El territorio y su imagen, Vol 1. Universidad de Malaga and Consejería de Medio Ambiente de la Junta de Andalucía, Malaga, p 515-526

Gómez Martín MA, Palomeque FL (2001) Tourism, territory and marginality: principles and case studies. Paper presented at: Annu Conf Int Geogr Union, Commission on Evolving Issues of Geographic Marginality in the Early 21st Century World, Stockholm

Gómez-Martín MB (2006) Climate potential and tourist demand in Catalonia (Spain) during the summer season. Clim Res 32:75-87

Gössling S, Hall CM (2006) Uncertainties in predicting tourist travel flows based on models. Editorial essay. Clim Change 79:163-173

Gössling S, Bredberg M, Randow A, Svensson P, Swedlin E (2006) Tourist perceptions of climate change: a study of international tourists in Zanzibar. Curr Issues Tourism 9: 419-435

Hamilton JM, Lau MA (2005) The role of climate information in tourist destination choice decision-making. In: Gössling $\mathrm{S}$, Hall CM (eds) Tourism and global environmental change. Routledge, London, p 229-250

Hill A (2009) Holiday deals abroad vanish in rush to flee the rain. Observer, London, 9 August. www.guardian.co.uk/ business/2009/aug/09/holiday-last-minute-bookings-increase

Holland E (2009) Sunshine guaranteed or your money back. The Matador Network, 9 May. http://matadornetwork. $\mathrm{com} / \mathrm{pulse} /$ sunshine-guaranteed-or-your-money-back/

Jones B, Scott D (2006) Climate change, seasonality and visitation to Canada's national parks. J Parks Recreation Adm 24:42-62

Jorgensen F, Solvoll G (1996) Demand models for inclusive tour charter: the Norwegian case. Tourism Manage 17: $17-24$

Katz RW, Murphy AH (1997) Economic value of weather and climate forecasts. Cambridge University Press, Cambridge
König U, Abegg A (1997) Impacts of climate change on tourism in the Swiss Alps. J Sustainable Tourism 5:46-58

Kozak M (2002) Comparative analysis of tourist motivations by nationality and destinations. Tourism Manage 23: 221-232

KPMG (2008) Climate changes your business. KPMG, Amstelveen. www.kpmg.nl/sustainability

Lanquar R, Hollier R (1986) Le marketing touristique. Que sais-je? No. 1911. Presses Universitaires de France, Paris

Lohmann M, Kaim E (1999) Weather and holiday preference-image, attitude and experience. Rev Tourisme 54: $54-64$

McBoyle G (2007) Approaching tourism through climate. In: Wall G (ed) Approaching tourism. Dep Geogr Occas Publ 21. University of Waterloo, Waterloo, p 35-51

> Mieczkowski Z (1985) The tourism climate index: a method for evaluating world climates for tourism. Can Geogr 29: $220-233$

Mintel International Group (1991) Special report-holidays. Leisure Intelligence, Mintel International Group, London

> Moreno A (2010) Mediterranean tourism and climate (change): a survey-based study. Tourism Hospitality Plan Dev 7: $253-265$

Moreno A, Amelung B, Santamarta L (2008) Linking beach recreation to weather conditions: a case study in Zandvoort, Netherlands. Tourism Mar Environ 5:111-120

National Research Council (2006) Critical issues in weather modification research. Committee on the Status and Future Directions in US Weather Modification Research and Operations. National Research Council, Washington, DC

> Parry M, Lowe J, Hanson C (2009) Overshoot, adapt and recover. Nature 458:1102-1103

Perry A (1993) Climate and weather information for the package holiday-maker. Weather 48:410-414

Rutty M, Scott D (2010) Will the Mediterranean be 'too hot' for tourism? Tourism Hospitality Plan Dev 7:267-281

Scott D (2006) Climate change and sustainable tourism in the 21st century. In: Cukier J (ed) Tourism research: policy, planning, and prospects. Dep Geogr Publ Ser. University of Waterloo, Waterloo, p 175-248

Scott D, Jones B, McBoyle G (2005) Climate, tourism and recreation: a bibliography-1936 to 2005. University of Waterloo, Waterloo

Scott D, Amelung B, Becken S, Ceron JP and others (2008a) Technical report. In: Climate change and tourism: responding to global challenges. UNWTO, Madrid, UNEP, Paris, and WMO, Geneva, p 23-237

Scott D, Gössling S, de Freitas C (2008b) Preferred climate for tourism: case studies from Canada, New Zealand and Sweden. Clim Res 38:61-73

Smith K (1981) The effect of weather conditions on the public demand for meteorological information. J Climatol 1: 381-393

Smith K (1990) Tourism and climate change. Land Use Policy $7: 176-180$

Smith K (1993) The influence of weather and climate on recreation and tourism. Weather 48:398-404

Sorensen J (2000) Hazard warning systems: review of 20 years of progress. Nat Hazards Rev 1:119-125

Stewart TR, Pielke R Jr, Nath R (2004) Understanding user decision making and the value of improved precipitation forecasts: lessons from a case study. Bull Am Meteorol Soc 85:223-235

Szalai K, Ratz T (2006) Tourist perceptions of uncertainty and risk associated with extreme weather events. Paper presented at: 3rd Int Conf, Tourism Future Trends. University 
Faculty of Tourism and Hotel Management, Sharm el Sheikh, Egypt, 6 October

UNCTAD (United Nations Conference on Trade and Development) (2008) UNCTAD handbook of statistics 2008. UN, New York

UNWTO (United Nations World Tourism Organization) (1998) Handbook on natural disaster reduction in tourist areas. UNWTO, Madrid, and WMO, Geneva

UNWTO (2001) Tourism 2020 vision. UNWTO, Madrid

UNWTO (2007) Compendium of tourism statistics, 2007 edn. UNWTO, Madrid

UNWTO (2008) Emerging tourism markets - the coming economic boom. Press release, 24 June. UNWTO, Madrid

UNWTO (2009) World tourism barometer - June 2009 UNWTO, Madrid. www.unwto.org/facts/eng/pdf/barometer/ UNWTO_Barom09_2_en_excerpt.pdf

UNWTO-UNEP-WMO (United Nations World Tourism Organization, United Nations Environment Programme and World Meteorological Organization) (2008) Climate change and tourism: responding to global challenges. UNWTO, Madrid, UNEP, Paris, and WMO, Geneva

Vancouver Island Tourism (2010) Storm watchingTofino \& Westcoast Vancouver Island, BC http://www.

Submitted: May 14, 2010; Accepted: October 18, 2010 vancouverisland.com/recreation/?id=172

- Wall G, Badke C (1994) Tourism and climate change: an international perspective. J Sustainable Tourism 2:193-203

Williams P, Dousa K, Hunt J (1997) The influence of weather context on winter resort valuations by visitors. J Travel Res $36: 29-36$

Wilton D, Wirjanto T (1998) An analysis of the seasonal variation in the national tourism indicators. Canadian Tourism Commission, Ottawa

WMO (World Meteorological Organization) (2007) Secure and sustainable living: social and economic benefits of weather, climate and water services. Madrid, Spain, 19-22 March 2007. Conference statement and action plan. www.preventionweb.net/english/professional/publications/ v.php?id=2621

World Travel and Tourism Council (2010) Tourism impact data and forecasts. World Travel and Tourism Council, London. www.wttc.org/eng/Tourism_Research/Tourism_ Economic_Research

Zaninovic K, Matzarakis A (2009) The bioclimatological leaflet as a means conveying climatological information to tourists and the tourism industry. Int $\mathrm{J}$ Biometeorol 53: 369-374

Proofs received from author(s): January 18, 2011 